\title{
A Well-to-Wheel Comparative Life Cycle Assessment Between Full Electric and Traditional Petrol Engines in the European Context
}

\author{
Filippo Cucinotta, Marcello Raffaele, and Fabio Salmeri $\left.{ }^{(}\right)$ \\ Department of Engineering, University of Messina, Contrada Di Dio (S. Agata), \\ 98166 Messina, Italy \\ fsalmeri@unime.it
}

\begin{abstract}
Automotive sector is crucial for the economic and social system. Conversely, it also plays an important role in the global emissions balance with strong consequences on the environment. Currently the Research world is engaged in the reduction of the emissions, especially in order to contrast the Climate Change and reduce toxicity on humans and the ecosystem. This study presents a comparative Life Cycle Assessment, Well-to-Wheel, between the most common technology used in the automotive sector, i.e. the traditional petrol Internal Combustion Engine and the full Battery Electric Vehicle. The different configurations have been analysed within 17 different impact categories in terms of climate change, human health, resourced depletion and ecosystems. The Well-to-Wheel approach allows to focus the attention on the use stage of the vehicle, considering the local effects due to the direct emissions in high density urban zones and it mitigates the dependence of usage hypotheses, different scenarios and intrinsic differences between the various models of cars in circulation.
\end{abstract}

Keywords: Life Cycle Assessment · Electric vehicles · Green design · Climate Change

\section{Introduction}

Road transport is the third largest source of European greenhouse gases accounting for around $26 \%$ of total emissions [1]. In the UK, e.g., conventional road transport also remains the predominant source of many local emissions including nitrogen oxides (NOx) and particulates (PMs). Within urban areas, the percentage contributions due to road transport are particularly high. For example, although road transport is responsible for around a quarter of particulates on a national level, in London road transport contributes almost $60 \%$ of known primary emissions [2]. Worldwide population growth and industrialization have resulted in increases in demand for energy in the transportation sector, among other sectors. As a result, air pollution and anthropogenic greenhouse gas emissions have become key global problems. Various options are available to mitigate 
the effect of the road emissions. The use of alternative fuels, mainly biodiesel, petrolalcohol blends, natural gas and liquefied petrol gas in vehicular applications has grown in recent years in European Union countries, the United States, Japan, India, Brazil and many other markets. Legislation is also in place to encourage or effectively force further adoption of these fuel types [3]. European Union requirements regarding vehicle emissions for passenger cars and light commercial vehicles, specified as Euro 6, set strong limits for emissions of $\mathrm{HC}, \mathrm{CO}$, and NOx. Instead, $\mathrm{Co}_{2}$ emissions are covered by separate legislation. The Life Cycle Assessment (LCA) is a very valid method in order to evaluate the real impact of a process or a product $[4,5]$. In particular, the Well-to-Wheel approach (WTW) allows to better emphasize on the usage phase, focusing on aspects relating to emissions in urban areas and more specifically verifying aspects related to engines and the production and refining of fuels [6].

\section{Materials and Methods}

The LCA analysis has been carried out with OpenLCA software version 1.10.1 [7], integrated with the ecoinvent database version 3.6 [8]. The allocation of the environmental burden has been handled by means of the cut-off system. In this way, if a material is recycled, the primary producer does not receive any credit for the provision of any recyclable materials. As a consequence, recyclable materials are available burden-free to recycling processes, and secondary (recycled) materials bear only the impacts of the recycling processes. Recyclable materials have been selected on the European market for products, consequently they include all the upstream burdens included average transports of that product within the geography, as well as inputs of the product itself to cover losses in trade and transport [8].

The consumption is stated, depending on the propulsion concept, in litre petrol per $100 \mathrm{~km}$, for the traditional Internal Combustion Engine (ICE) and in kilowatt-hours per $100 \mathrm{~km}$, for the Battery Electric Vehicle (BEV). For a general comparison, the energy consumption is converted in $\mathrm{MJ} / 100 \mathrm{~km} / 100$ installed-kW as well for tank-to-wheel and well-to-tank approach. The consumption per kilometre of a car is strongly influenced by several factors, among which the most important are speed, weight and aerodynamics. In order to make a comparison between the different powertrains, a car model was chosen, looking for those on the market, sedan-type cars (with 3 volumes), with similar, as much as possible, installed power, of the same segment (medium) and of the same year of production (2018). The choice was for a Mercedes C-Klasse with a petrol $155 \mathrm{~kW}$ internal combustion engine $\left(1991 \mathrm{~cm}^{3}\right)$ and a Tesla model S with a $193 \mathrm{~kW}$ electric engine.

This particularly affects the energy mix referred to in the production of electricity for recharging electric car batteries but also the emission related to the petrol production and distribution. In all cases, reference was made to urban driving in areas with high population density. The electricity market activity ends with the transport of the energy at low voltage $(400 \mathrm{~V})$ electricity in the transmission network over aerial lines and cables. The ecoinvent dataset includes: electricity inputs produced in this country and from imports and transformed to low voltage; the transmission network; direct emissions to air; electricity losses during transmission. The dataset is extrapolated from year 2017 
to the year of the calculation (2019). The energy mix change greatly in function of the natural resources and the political choices of the country. The Well-to-Tank (WTT) stage includes fuel extraction, refining and distribution for ICE vehicles and, electrical energy production, transformation and distribution for BEVs. The Tank-to-Wheel (TTW) stage includes the fuel combustion for ICE while it has not emissions for BEVs. The Life Cycle Impact Assessment (LCIA) has been conducted according to the ILCD 2018 method [9]. In this work, the midpoint methodology has been adopted. The ILCD midpoint categories are grouped into four areas of protection: Climate Change (CC), Human Health (HH), Resources Depletion (RD) and Ecosystems (EQ). The impact categories of the endpoint method are those of IPCC for CC [10], of Posch et al. [11] for EQ, Henderson et al. [12], Frischknecht et al. [13], for HH and van Oers and Guinée [14], Milà I Canals et al. [15], van Oers et al. [16] for RD.

\section{Results and Discussion}

The emission factors, expressed in $\mathrm{g} / 100 \mathrm{~km}$, have been taken from the specialized site https://ecoscore.be for the two chosen cars. These emissions are related only to the use phase of the vehicle, i.e. they are the pollutants emitted while driving. A share of these emissions depends on engine technology, another part on the fuel type and fuel consumption, and a third part is measured during the official approval tests a vehicle has to undergo before it can enter the European market. The specific TTW emissions for the ICE vehicle are $12800 \mathrm{~g} / 100 \mathrm{~km}$ of CO2, $23.3 \mathrm{~g} / 100 \mathrm{~km}$ of CO, $0.4 \mathrm{~g} / 100 \mathrm{~km}$ of NOx and $2.9 \mathrm{~g} / 100 \mathrm{~km}$ of HC. The estimated energy consumption is of $249 \mathrm{MJ} / 100 \mathrm{~km}$ (corresponding to a petrol consumption of $8.4 \mathrm{l} / 100 \mathrm{~km}$ ) for the ICE vehicle, and an estimated energy consumption of $78.1 \mathrm{MJ} / 100 \mathrm{~km}$ for the BEV. The results are reported for $100 \mathrm{~km}$ and for $100 \mathrm{~kW}$ of installed power, according to the ILCD 2018 method. Each emission is reported in terms of equivalent unit and is categorized in the different areas of protection. Furthermore, the data are represented as a percentage comparison, making the ICE vehicle as 100 , i.e. $\left(\mathrm{BEV}_{\text {emission }}-\mathrm{ICE}_{\text {emission }}\right) / \mathrm{ICE}_{\text {emission }} \%$. In this way a positive result indicates that the BEV has a higher impact on the environment and vice versa.

The global results for $100 \mathrm{~km}$ and for $100 \mathrm{~kW}$ of installed power, according to the ILCD 2018 method, are reported in Fig. 1. Each emission is reported in terms of percentage difference between the BEV and the ICE referring to the European average. The standard deviation shows a great variability of the data, especially in function of the electricity mix of the country. Focusing on some particular impact category, it is possible to see better the difference in terms of country (see Fig. 2) yellow has been attributed to a zero difference between ICE and BEVs, green to a better impact and red to a worst impact. 


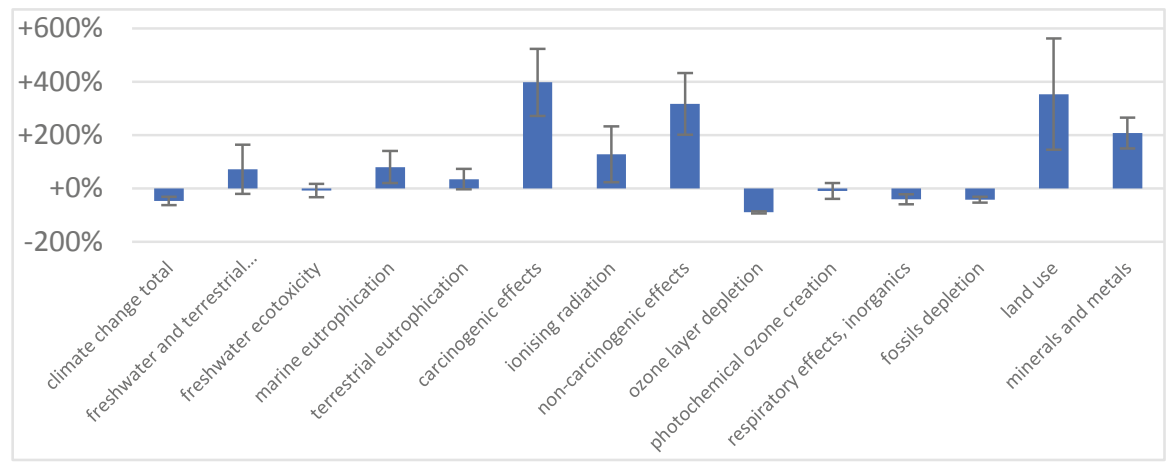

Fig. 1. Impact effect for $100 \mathrm{~km}$ and $100 \mathrm{~kW}$ of installed power

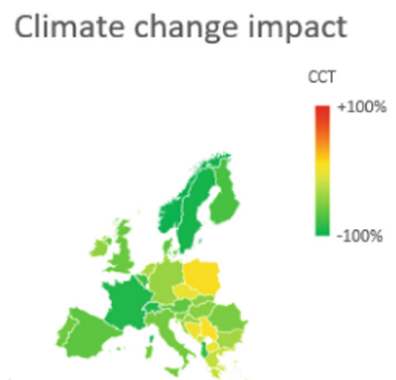

(a)

lonizing radiations

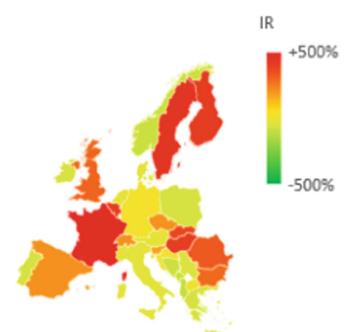

(c)

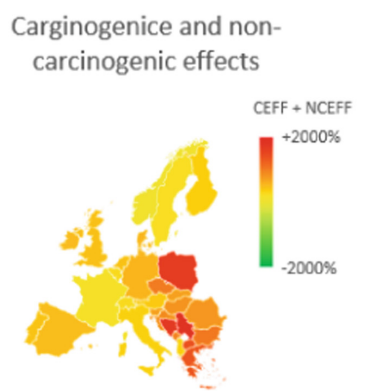

(b)

Marine eutrophication

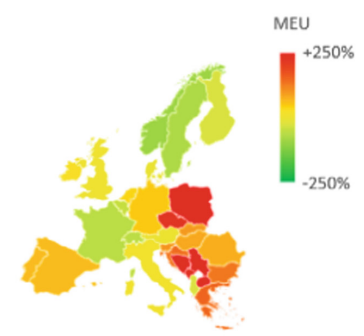

(d)

Fig. 2. Comparison of the impacts of BEV, respect to ICE, for different categories of impact

\section{Conclusions}

A comparative Well-To-Wheel Life Cycle Assessment among an ICE and a similar BEV, has been carried out in the most relevant European countries. The impact categories analysed have been based on the ILCD 2018 method with the ecoinvent database (year 2019) and the OpenLCA software.

The finding obtained are summarized as follows: 
- Electric vehicles play a fundamental role in the battle against Climate Change, since they lead to a WTW reduction until 50\% compared to the traditional ICE vehicles, with small exceptions in countries heavily dependent on fossil fuels;

- Conversely, BEVs have a generally higher impact on categories related to human health;

- The eutrophication of the waters (marine and fresh) and of the soil is highly dependent on the energy production methods;

- Countries with electricity produced by means of nuclear power plants have very good performance in terms of Climate Change but have major repercussions on ionizing radiation and dissipated water;

- The WTW approach allowed to focus on the fuel impact but doesn't consider construction, maintenance and dismantling of the vehicles.

\section{References}

1. UNFCCC: Greenhouse gas emissions by country and sector (infographic). https://www.eur oparl.europa.eu/news/en/headlines/society/20180301STO98928/greenhouse-gas-emissionsby-country-and-sector-infographic

2. DEFRA: Air Pollution in the UK 2015 (2016)

3. Directive 2009/28/EC of The European Parliament and of The Council of 23.04.2009 on the promotion of the use of energy from renewable sources and amending and subsequently repealing Directives 2001/77/EC and 2003/30/EC. Official J. Eur. UN (2009)

4. Barone, S., Cucinotta, F., Sfravara, F.: A comparative life cycle assessment of utility poles manufactured with different materials and dimensions. In: Eynard, B., Nigrelli, V., Oliveri, S., Peris-Fajarnes, G., Rizzuti, S. (eds.) Advances on Mechanics, Design Engineering and Manufacturing, pp. 91-99. Springer, Cham (2017). https://doi.org/10.1007/978-3-319-457819_10.

5. Cucinotta, F., Guglielmino, E., Sfravara, F.: Life cycle assessment in yacht industry: a case study of comparison between hand lay-up and vacuum infusion. J. Clean. Prod. (2016). https:// doi.org/10.1016/j.jclepro.2016.10.080

6. Campanari, S., Manzolini, G., Garcia de la Iglesia, F.: Energy analysis of electric vehicles using batteries or fuel cells through well-to-wheel driving cycle simulations. J. Power Sources 186, 464-477 (2009). https://doi.org/10.1016/j.jpowsour.2008.09.115.

7. Ciroth, A.: ICT for environment in life cycle applications openLCA - a new open source software for life cycle assessment. Int. J. Life Cycle Assess. 12, 209-210 (2007). https://doi. org/10.1065/lca2007.06.337

8. Wernet, G., Bauer, C., Steubing, B., Reinhard, J., Moreno-Ruiz, E., Weidema, B.: The ecoinvent database version 3 (part I): overview and methodology. Int. J. Life Cycle Assess. 21, 1218-1230 (2016). https://doi.org/10.1007/s11367-016-1087-8

9. European Commission - Joint Research Centre - Institute for Environment and, Sustainability: International Reference Life Cycle Data System (ILCD) Handbook - General guide for Life Cycle Assessment - Detailed guidance, Luxembourg (2010). https://doi.org/10.2788/38479

10. Intergovernmental Panel on Climate Change (IPCC): Climate change 2007: Synthesis report (2008). https://doi.org/10.1256/004316502320517344.

11. Posch, M., Seppälä, J., Hettelingh, J.P., Johansson, M., Margni, M., Jolliet, O.: The role of atmospheric dispersion models and ecosystem sensitivity in the determination of characterisation factors for acidifying and eutrophying emissions in LCIA. Int. J. Life Cycle Assess. 13, 477-486 (2008). https://doi.org/10.1007/s11367-008-0025-9 
12. Henderson, A.D., Hauschild, M.Z., Van De Meent, D., Huijbregts, M.A.J., Larsen, H.F., Margni, M., McKone, T.E., Payet, J., Rosenbaum, R.K., Jolliet, O.: USEtox fate and ecotoxicity factors for comparative assessment of toxic emissions in life cycle analysis: sensitivity to key chemical properties. Int. J. Life Cycle Assess. 16, 701-709 (2011). https://doi.org/10. 1007/s11367-011-0294-6

13. Frischknecht, R., Braunschweig, A., Hofstetter, P., Suter, P.: Human health damages due to ionising radiation in life cycle impact assessment. Environ. Impact Assess. Rev. 20, 159-189 (2000). https://doi.org/10.1016/S0195-9255(99)00042-6

14. van Oers, L., Guinée, J.: The abiotic depletion potential: background, updates, and future. Resources 5 (2016). https://doi.org/10.3390/resources5010016.

15. Milà I Canals, L., Bauer, C., Depestele, J., Dubreuil, A., Knuchel, R.F., Gaillard, G., Michelsen, O., Müller-Wenk, R., Rydgren, B.: Key elements in a framework for land use impact assessment within LCA. Int. J. Life Cycle Assess. 12, 5-15 (2007). https://doi.org/10. 1065/lca2006.05.250.

16. van Oers, L., De Koning, A., Guinée, J.B., Huppes, G.: Abiotic resource depletion in LCA. Public Work. Water Manag. 1-75 (2002)

Open Access This chapter is licensed under the terms of the Creative Commons Attribution 4.0 International License (http://creativecommons.org/licenses/by/4.0/), which permits use, sharing, adaptation, distribution and reproduction in any medium or format, as long as you give appropriate credit to the original author(s) and the source, provide a link to the Creative Commons license and indicate if changes were made.

The images or other third party material in this chapter are included in the chapter's Creative Commons license, unless indicated otherwise in a credit line to the material. If material is not included in the chapter's Creative Commons license and your intended use is not permitted by statutory regulation or exceeds the permitted use, you will need to obtain permission directly from the copyright holder.

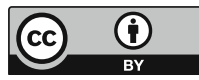

